\title{
KAJIAN PROGRAM PEMBERDAYAAN EKONOMI KELUARGA UNTUK PENINGKATAN AKSES PANGAN
}

\author{
(Study on Family Economic Empowerment Programs to Improve Food Access)
}

\author{
Dadang Sukandar ${ }^{1 *}$, Ali Khomsan ${ }^{1}$, dan Tin Herawati ${ }^{2}$ \\ ${ }^{1 *}$ Alamat Korespondensi: Departemen Gizi Masyarakat, Fakultas Ekologi Manusia, Institut Pertanian \\ Bogor, Bogor 16680. Telp: 0251-8621258; Fax: 0251-8622276; E-mail: Ipkbiner@yahoo.com \\ 1 Departemen Gizi Masyarakat, Fakultas Ekologi Manusia, Institut Pertanian Bogor, Bogor 16680 \\ 2 Departemen Ilmu Keluarga dan Konsumen, Fakultas Ekologi Manusia, Institut Pertanian Bogor, \\ Bogor 16680
}

\begin{abstract}
The objectives of the study were to identify national programms of family economic empowerment, to analyze social-economics of program participants, to evaluate the family economics program, to analize impacts of family economic programs toward food access and to create recommendation for improving family economic empowerment programs. This study was conducted in Pamijahan sub-dsitrict of Bogor districts and in Bogor Barat and Bogor Utasra sub-district of Bogor municipality in the period of March to November 2009. Sampling method used was stratified random sampling with equal proportion where the total sample size was 48 households. Data collected include household socio-economics, food consumption of before and after programs and bussines input, proceses and output of before and after program. The results show that the input, process and output of the programs i.e. PNPM Mandiri, Garda Emas, P2KP and KUBE were relatyively good. All of the programs are effective because their 1/Cost-Effective are higher than 1. The probability of Garda Emas to be succesfull is highest (0.89), while the probability of Mandiri, Dakabalarea, P2KP, Kube are $0.80,0.27,0.36$ and 0.72 respectively.
\end{abstract}

Keywords: PNPM Mandiri, Dakabalarea, P2KP, Garda Emas, Kube, cost-effectiveness.

\section{PENDAHULUAN}

Kemiskinan dan kesejahteraan menjadi isu penting di negara besar seperti Indonesia ini, karena peningkatan ekonomi makro yang selama ini sering disuarakan pemerintah ternyata masih banyak menyisakan pekerjaan rumah berupa angka kemiskinan yang tak kunjung turun dan lapangan kerja yang masih sulit (Khomsan, 2007). Krisis ekonomi pada tahun 1998 meningkatkan jumlah orang miskin menjadi $24.2 \%$. Setelah hampir satu dekade jumlah orang miskin turun menjadi $17.8 \%$ (2006), namun angka ini ternyata masih lebih tinggi daripada jumlah orang miskin tahun 2005 (16.0\%).

Di pedesaan, kemiskinan semakin menyeruak karena pemilikan lahan produksi yang semakin sempit. Hal ini mendorong pengangguran terselubung atau melahirkan buruhburuh baru di sektor pertanian sehingga bersemailah bibit kemiskinan yang terus berkembang bagaikan lingkaran spiral yang makin besar.

Ada dua langkah besar yang bisa diambil untuk mengatasi kemiskinan dan ketidak sejahteraan. Pertama, penyediaan fasilitas umum dan sosial kepada masyarakat kurang mampu. Misalnya, pendidikan dasar gratis, pelayanan kesehatan gratis, meningkatkan ketersediaan fasilitas air bersih, penetapan tarif listrik dan harga BBM yang murah. Kedua, pemerintah harus mendorong terbukanya lapangan kerja yang lebih luas, termasuk di dalamnya pemberian kredit mikro dalam skala rumahtangga untuk menggerakkan ekonomi keluarga seperti TAKESRA, KUKESRA, atau PNPM Mandiri. Di samping itu, pemberian bantuan langsung juga akan sangat membantu masyarakat miskin seperti BLT dan raskin.

Pemberdayaan ekonomi keluarga miskin melalui program-program pemerintah adalah merupakan upaya kongkrit untuk pengentasan kemiskinan. Keluarga merupakan kelompok yang terdiri dari dua orang atau lebih yang terikat melalui hubungan darah, perkawinan atau adopsi dan tinggal bersama. Keluarga inti (nuclear family) adalah kelompok yang terdiri dari ayah, ibu, dan anak yang tinggal bersama. Keluarga besar (extended family) mencakup keluarga inti ditambah kerabat lain seperti 
kakek, nenek, paman, bibi, sepupu, dan kerabat karena perkawinan (Engel, Blackwell \& Miniard, 1992).

Keluarga mempunyai peranan yang sangat penting karena merupakan lembaga yang pertama memperkenalkan peradaban dunia kepada manusia. Keluarga merupakan tempat dalam menanamkan nilai-nilai yang ada dalam masyarakat. Selain itu, keluarga memiliki posisi strategis dalam pembangunan sumberdaya manusia yang berkualitas karena manusia berada dalam keluarga pada masa awal pertumbuhan dan perkembangannya (Amrullah, 2000).

Program pemberdayaan ekonomi masyarakat merupakan program penanggulangan masalah kemiskinan dan menjadi salah satu program prioritas pembangunan. Program pemberdayaan ekonomi masyarakat banyak dibentuk sebagai upaya pemerintah mengatasi masalah krisis ekonomi yang dimulai tahun 1997. Banyak bentuk program pemberdayaan ekonomi masyarakat, lima program di antaranya yaitu Dakabalarea, Gerakan Pemberdayaan Ekonomi Masyarakat (Garda Emas), Proyek Penanggulangan Kemiskinan di Perkotaan (P2KP), Kelompok Usaha Bersama Keluarga Miskin (KUBE) dan Program Nasional Pemberdayaan Masyarakat (PNPM) Mandiri.

Penelitian ini akan mengkaji programprogram pemberdayaan ekonomi keluarga dan dampaknya terhadap akses pangan rumahtangga. Diharapkan penelitian ini dapat menghasilkan rekomendasi bagi perbaikan program pengentasan kemiskinan baik di tingkat kota/ kabupaten maupun nasional.

Tujuan penelitian ini adalah (1) mengidentifikasi program-program nasional di bidang pemberdayaan ekonomi keluarga, (2) menganalisis keadaan sosial ekonomi keluarga penerima bantuan program-program pemberdayaan ekonomi keluarga, (3) mengevaluasi programprogram pemberdayaan ekonomi keluarga, (4) menganalisis dampak program-program ekonomi keluarga terhadap akses pangan, (5) menyusun rekomendasi untuk perbaikan program pemberdayaan ekonomi keluarga.

\section{METODE PENELITIAN}

\section{Desain, Tempat, dan Waktu Penelitian}

Penelitian ini merupakan studi deskriptif dengan rancangan cross-sectional. Penelit1a币. ini dilaksanakan di Kelurahan Cimayang, Kecamatan Pamijahan (Kabupaten Bogor), Kelurahan Cilendek Timur, dan Kelurahan Bubulak,
Kecamatan Bogor Barat, dan Kelurahan Ciluar, Kecamatan Bogor Utara (Kota Bogor). Waktu penelitian Maret-Nopember 2009.

\section{Jumlah dan Cara Penarikan Contoh}

Contoh ialah peserta program pemberdayaan ekonomi yaitu masyarakat yang memiliki usaha dan mengajukan bantuan dari adanya program pemberdayaan tersebut serta telah menjadi peserta program pemberdayaan minimal selama satu tahun. Jumlah populasi Pemilihan contoh dilakukan secara acak sederhana. Berdasarkan kriteria tersebut diperoleh populasi sampel program PNPM Mandiri sebanyak 20 orang, program GARDA EMAS sebanyak 28 orang dan program KUBE sebanyak 57 orang. Dari masing-masing populasi sampel yang ada diambil 10 orang (populasi contoh) secara acak kecuali pada program Dakabalarea diambil seluruhnya sehingga total keseluruhan jumlah populasi contoh adalah 48 orang.

\section{Jenis dan Cara Pengumpulan Data}

Jenis data primer yang dikumpulkan meliputi karakteristik keluarga contoh (usia, jenis kelamin, besar anggota keluarga, status dalam keluarga, berat badan, tinggi badan, pendidikan, pekerjaan, pendapatan dan pengeluaran), akses ekonomi keluarga contoh, akses fisik keluarga contoh, akses sosial keluarga contoh, konsumsi pangan keluarga contoh, tingkat konsumsi energi dan protein keluarga contoh, input, proses serta output program pemberdayaan ekonomi. Jenis data sekunder yang dikumpulkan meliputi keadaan umum lokasi penelitian (profil kelurahan), daftar lokasi pelaksanaan program pemberdayaan ekonomi, dan daftar peserta program pemberdayaan ekonomi. Pengumpulan data dilakukan dengan menggunakan kuesioner dan observasi langsung terhadap responden. Data-data yang telah diperoleh ditabulasikan dan dianalisis dengan bantuan paket program Microsoft Excel dan Statistical Program for Social Science (SPSS) 16.0 for Windows. Analisis data yang dilakukan ialah analisis deskriptif dan analisis korelasi, uji t-student, dan analisis cost-effectiveness program PNPM Mandiri.

\section{HASIL DAN PEMBAHASAN}

\section{Program PNPM Mandiri}

PNPM Mandiri secara nasional dimulai sejak tahun 1997, namun di Kabupaten Bogor baru dimulai pada tahun 2003. Dana PNPM 
bersumber $100 \%$ dari Pemerintah Pusat. Besarnya alokasi dana tiap desa ditentukan oleh Musyawarah Antar Desa (MAD) di dalamnya terdapat MKP yaitu Musyawarah Khusus Perempuan.

Pada tahun 2003 di Kabupaten Bogor penerima program ini baru empat Kecamatan yaitu: Sukamakmur, Pamijahan, Babakan Madang, dan Tenjolaya. Bantuan Langsung Masyarakat (BLM) yang diserahkan sebesar 1 Milyar/kecamatan dengan komposisi untuk fisik $75 \%$ dan untuk ekonomi sebesar $25 \%$.

Pada tahun 2007 terdapat penambahan jumlah kecamatan penerima program yaitu: Jasinga, Cigudeg, Leuwiliang, dan Ciampea. Jadi total jumlah penerima yaitu 8 Kecamatan. Dana yang dikucurkan masih sama dengan tahun-tahun sebelumnya yaitu Rp. 1 milyar/kecamatan.

Pada tahun 2008 terjadi penambahan 1 kecamatan lagi yaitu Leuwisadeng. Jadi total penerima yaitu 9 kecamatan. Jumlah dana yang dikucurkan 11 Milyar 400 juta untuk pusat dan untuk daerah sebesar 3 Milyar 850 juta.

Pada tahun 2009 jumlah kecamatan penerima program menjadi 21 kecamatan yaitu ditambah: Jonggol, Klapanunggal, Tamansari, Megamendung, Dramaga, Ciseeng, Gunung Sindur, Rumpiin, Parung Panjang, Nanggung, dan Tenjolaya. Jumlah dana yang dikucurkan 8 Milyar 400 juta untuk pusat dan 33 Milyar 600 juta untuk daerah. Pada tahun 2009, Kecamatan Ciampea tidak diikutsertakan karena sudah tergabung dalam program PNPM perkotaan.

Ruang lingkup kegiatan PNPM Mandiri pada dasarnya terbuka bagi semua kegiatan penanggulangan kemiskinan yang diusulkan dan disepakati masyarakat, meliputi:

1. Penyediaan dan perbaikan prasarana/sarana lingkungan permukiman, sosial dan ekonomi secara kegiatan padat karya.

2. Penyediaan sumberdaya keuangan melalui dana bergulir dan kredit mikro untuk mengembangkan kegiatan ekonomi masyarakat miskin. Perhatian yang lebih besar diberikan bagi kaum perempuan untuk memanfaatkan dana bergulir ini.

3. Kegiatan terkait peningkatan kualitas sumberdaya manusia, terutama yang bertujuan mempercepat pencapaian target MDGs.

4. Peningkatan kapasitas masyarakat dan pemerintahan lokal melalui penyadaran kritis, pelatihan ketrampilan usaha, manajemen organisasi dan keuangan, serta penerapan tata kepemerintahan yang baik.

\section{Keadaan sosial ekonomi}

Umur

Pada beberapa literatur, banyak disebutkan bahwa yang dimaksud dengan angkatan produktif adalah penduduk berumur antara 15-64 tahun (Lembaga Demografi UI 1981). Berpijak pada batasan tersebut, maka dapat dikatakan sebagian besar responden berada pada kelompok usia kerja. Berdasarkan Tabel 1 dapat dilihat bahwa rata-rata umur suami adalah 48.9 tahun dan istri 41.6 tahun. Rata-rata umur suami tertinggi (58.3 tahun) ditemukan pada responden peserta program Dakabalarea dan rata-rata umur terendah (44.6 tahun) terdapat pada responden peserta program Kube. Sama halnya dengan suami, rata-rata umur istri tertinggi (51.6) ditemukan pada peserta program Dakabalarea namun rata-rata umur istri terendah terdapat pada peserta program PNPM Mandiri (39.6). Jika dilihat dari umur suami dan istri yang sebagian besar tergolong produktif, dapat dikatakan bahwa keluarga memiliki sumberdaya yang cukup produktif untuk mencari nafkah.

\section{Tingkat pendidikan}

Tingkat pendidikan di suatu wilayah pada umumnya akan mencerminkan keragaman mata pencaharian yang dijalani penduduk di wilayah tersebut. Dapat dikatakan bahwa pendidikan suami peserta program pemberdayaan adalah rendah. Hal ini dapat dilihat pada Tabel 4 bahwa sebagian besar suami adalah berpendidikan sekolah dasar. Keadaan tersebut terlihat jelas terutama pada suami peserta PNPM, Kube dan P2KP, dimana lebih dari 50 persen anggotanya berpendidikan sekolah dasar. Data penelitian ini juga menunjukkan bahwa terdapat 30 persen suami peserta program PNPM berpendidikan perguruan tinggi. Hal yang berbeda terlihat pada program Garda Mas, dimana sebagian besar suami berpendidikan SLTA.

Hal yang sama dengan tingkat pendidikan suami, maka sebagian besar pendidikan istri juga adalah sekolah dasar. Keadaan ini tampak jelas terutama pada isteri peserta program PNPM, Kube dan Dakabalarea, dimana lebih dari 60 persen isteri berpendidikan sekolah dasar (Tabel 2). Pendidikan isteri relatif lebih tinggi ditemukan pada peserta program Garda Mas, dimana sebanyak 44.4 persen isteri 
berpendidikan SLTP. Berdasarkan data pendidikan isteri dan suami maka dapat dikatakan bahwa peserta program Garda Mas memiliki tingkat pendidikan yang relatif lebih tinggi dibandingkan peserta program lainnya.

\section{Pendapatan Rumahtangga}

Menurut Tjahjana (2004), perbedaan pendapatan keluarga tidak saja disebabkan oleh tingkat pendidikan, akan tetapi juga disebabkan oleh beberapa faktor lain seperti pengalaman kerja, keahlian, sektor usaha, jenis usaha dan lokasi usaha.

Hasil analisis data menunjukkan bahwa rata-rata pendapatan rumah tangga adalah $\mathrm{Rp}$ 408 152. Rata-rata tertinggi (Rp 617 967) ditemukan pada rumah tangga peserta program Garda Mas dan terendah (Rp 172 242) pada program Kube. Pendapatan rumah tangga tertinggi adalah Rp 1762500 dan terendah yaitu
Rp 19 450, ditemukan pada peserta program P2KP (Tabel 3).

Evaluasi Input, Proses, dan Output Program

\section{PNPM Mandiri}

Input

Beberapa cakupan kegiatan PNPM adalah pemberian modal untuk kegiatan simpan pinjam wanita dan kegiatan usaha produktif. Oleh karena itu hasil penelitian menunjukkan bahwa semua penerima dari program tersebut memiliki usaha. Sebagian besar $(70 \%)$ usaha yang dijalankan merupakan usaha sendiri dan sebanyak 30 persen adalah usaha bersama keluarga. Jenis bantuan yang diterima oleh semua responden adalah dalam bentuk pinjaman uang, dengan rata-rata sebesar Rp 1038500 (Tabel 4). Adapun pinjaman terbesar mencapai Rp 1500000. Sebanyak 60 persen responden menyatakan bahwa jumlah uang yang diterima dipotong rata-rata sebesar Rp 21500 untuk sumbangan.

Tabel 1. Sebaran Suami dan Istri Berdasarkan Umur

\begin{tabular}{|c|c|c|c|c|c|c|c|c|c|}
\hline \multirow{2}{*}{ Program } & \multirow{2}{*}{$\mathrm{n}$} & \multicolumn{4}{|c|}{ Suami } & \multicolumn{4}{|c|}{ Istri } \\
\hline & & mean & sd & $\min$ & $\max$ & mean & sd & $\min$ & $\max$ \\
\hline PNPM & 9 & 47.6 & 14.9 & 23.0 & 70.0 & 39.6 & 11.7 & 21.0 & 53.0 \\
\hline Kube & 7 & 44.6 & 10.2 & 28.0 & 57.0 & 45.4 & 8.6 & 26.0 & 55.0 \\
\hline P2KP & 10 & 50.0 & 9.7 & 40.0 & 70.0 & 34.2 & 16.0 & 13.0 & 54.0 \\
\hline Dakabalarea & 7 & 58.3 & 10.4 & 47.0 & 76.0 & 51.6 & 8.1 & 37.0 & 63.0 \\
\hline Garda Emas & 8 & 44.8 & 5.6 & 39.0 & 53.0 & 41.0 & 6.8 & 30.0 & 53.0 \\
\hline Total & 41 & 48.9 & 11.2 & 23.0 & 76.0 & 41.6 & 12.4 & 6.0 & 63.0 \\
\hline
\end{tabular}

Tabel 2. Sebaran Responden Berdasarkan Tingkat Pendidikan

\begin{tabular}{|c|c|c|c|c|c|c|c|c|c|c|c|}
\hline \multirow[b]{2}{*}{ Program } & \multirow[b]{2}{*}{ Stat } & \multicolumn{5}{|c|}{ Suami } & \multicolumn{5}{|c|}{ Istri } \\
\hline & & Tdk Sekolah & SD & SLTP & SLTA & PT & $\begin{array}{c}\text { Tdk } \\
\text { Sekolah }\end{array}$ & SD & SLTP & SLTA & PT \\
\hline \multirow{2}{*}{ PNPM } & $\mathrm{n}$ & 1 & 5 & 3 & 0 & 0 & 1 & 5 & 2 & 0 & 0 \\
\hline & $\%$ & 11.1 & 55.6 & 33.3 & 0.0 & 0.0 & 12.5 & 62.5 & 25.0 & 0.0 & 0.0 \\
\hline \multirow{2}{*}{ Kube } & $\mathrm{n}$ & 1 & 5 & 3 & 0 & 0 & 2 & 6 & 1 & 1 & 0 \\
\hline & $\%$ & 11.1 & 55.6 & 33.3 & 0.0 & 0.0 & 20.0 & 60.0 & 10.0 & 10.0 & 0.0 \\
\hline \multirow{2}{*}{ P2KP } & $\mathrm{n}$ & 0 & 5 & 1 & 1 & 3 & 3 & 6 & 3 & 1 & 0 \\
\hline & $\%$ & 0.0 & 50.0 & 10.0 & 10.0 & 30.0 & 23.1 & 46.2 & 23.1 & 7.7 & 0.0 \\
\hline \multirow{2}{*}{ Dakabalarea } & $\mathrm{n}$ & 0 & 3 & 0 & 2 & 2 & 1 & 6 & 0 & 1 & 0 \\
\hline & $\%$ & 0.0 & 42.9 & 0.0 & 28.6 & 28.6 & 12.5 & 75.0 & 0.0 & 12.5 & 0.0 \\
\hline \multirow{2}{*}{ Garda Emas } & $\mathrm{n}$ & 0 & 2 & 1 & 6 & 0 & 0 & 4 & 4 & 1 & 0 \\
\hline & $\%$ & 0.0 & 22.2 & 11.1 & 66.7 & 0.0 & 0.0 & 44.4 & 44.4 & 11.1 & 0.0 \\
\hline \multirow{2}{*}{ Total } & $\mathrm{n}$ & 2 & 20 & 8 & 9 & 5 & 7 & 18 & 7 & 0 & 5 \\
\hline & $\%$ & 4.5 & 45.5 & 18.2 & 20.5 & 11.4 & 18.9 & 48.6 & 18.9 & 0.0 & 13.5 \\
\hline
\end{tabular}

Tabel 3. Statistik Pendapatan Rumahtangga (Rp/kap/bln)

\begin{tabular}{|c|c|c|c|c|c|}
\hline \multirow{2}{*}{ Program } & \multicolumn{5}{|c|}{ Statistik } \\
\hline & $\mathrm{n}$ & mean & sd & $\min$ & $\max$ \\
\hline PNPM & 10 & 318967 & 208323 & 33333 & 750000 \\
\hline Kube & 10 & 172242 & 104106 & 61667 & 420000 \\
\hline P2KP & 10 & 552395 & 507397 & 19450 & 1762500 \\
\hline Dakabalarea & 8 & 371951 & 183908 & 100000 & 590000 \\
\hline Garda Emas & 10 & 617967 & 518136 & 101667 & 1700000 \\
\hline Total & 48 & 408152 & 379052 & 19450 & 1762500 \\
\hline
\end{tabular}




\section{Proses}

Proses pemberdayaan adalah suatu rangkaian kegiatan pelaksanaan dari program kegiatan pemberdayaan. Pada penelitian ini beberapa indikator yang digunakan dalam proses pemberdayaan adalah teknis pengajuan bantuan, kesesuaian bantuan yang diberikan, ketepatan dalam pemberian bantuan, sosialisasi program, keikutsertaan peserta dalam sosialisasi, keberadaan sanksi dan adanya penghargaan terdapat kepatuhan peserta dalam mengikuti program.

Hampir semua penerima program $(90 \%)$ menyatakan bahwa untuk mengikuti program PNPM tidak perlu mengajukan surat permohonan bantuan. Jika dilihat dari besarnya bantuan, terdapat 30 persen penerima tidak puas dengan jumlah bantuan yang diberikan. Hampir semua penerima $(90 \%)$ patuh terhadap jadwal pengembalian bantuan dan sisanya $(10 \%)$ kadang-kadang patuh terhadap jadwal pengembalian yang telah ditetapkan. Jika penerima program tidak patuh terhadap jadwal yang telah ditetapkan maka terdapat beberapa sanksi yang diberikan. Menurut responden bentuk sanksi yang diberikan adalah denda dan jaminan barang. Selain sanksi, terdapat juga pengharagaan yang diberikan kepada penerima yang patuh terhadap jadwal pengembalian, yaitu peningkatan bantuan. Hal tersebut dinyatakan oleh semua penerima.

\section{Ouput}

Output kegiatan pemberdayaan adalah hasil atau kemajuan yang diperoleh oleh penerima program selama mengikuti kegiatan pemberdayaan. Beberapa output yang diamati dalam kajian ini adalah peningkatan pengha- silan, tingkat kemudahan memasarkan hasil usaha, keterampilan dalam berusaha serta peningkatan kerjasama dengan pihak lainnya. Idealnya hal-hal tersebut dapat dicapai oleh penerima program sebagai dampak dari bantuan modal dan pendampingan yang menjadi tugas pengelola program.

Berdasarkan penelitian di lapangan menunjukkan bahwa keberhasilan program PNPM dapat dirasakan oleh sebagian besar penerima program. Hal ini dapat dilihat dari sebagian besar $(90 \%)$ penerima mengalami peningkatan rata-rata penghasilan, pemasaran produk yang dijual lebih mudah (80\%) dan sebanyak 60 persen penerima merasa keterampilan usaha mereka meningkat setelah menerima bantuan. Beberapa hal yang dianggap meningkat setelah menerima bantuan adalah komoditas penjualan meningkat $(10 \%)$. Sementara dalam hal kerjasama, hanya 30 persen penerima yang mampu memperluas jaringan kerjasamanya.

\section{KUBE}

Input

Sebanyak 40 persen penerima bantuan menyatakan bahwa uang diterimanya tidak untuk sepenuhnya karena mengalami pemotongan. Potongan tersebut digunakan untuk sumbangan, tetapi ada 20 persen penerima yang menyatakan bahwa potongan tersebut adalah untuk tabungan. Rata-rata uang yang diterima oleh peserta program KUBE adalah Rp 650 000. Jumlah tersebut lebih kecil dibandingkan dengan bantuan program PNPM. Sedangkan rata-rata potongan bantuan adalah sebesar Rp 339400 dan rata-rata tabungan Rp 5450 (Tabel 5). Potongan untuk tabungan inilah yang tidak ditemukan di program PNPM.

Tabel 4. Statistik Penerima Program Menurut Pertanyaan Evaluasi Input Program PNPM Mandiri

\begin{tabular}{|c|c|c|c|c|c|c|}
\hline \multirow{2}{*}{ No. } & \multirow{2}{*}{ Jumlah uang (Rp) } & \multicolumn{5}{|c|}{ Statistik } \\
\hline & & $\mathrm{n}$ & mean & sd & $\min$ & $\max$ \\
\hline 1 & Bantuan yang diberikan & 10 & 1038500 & 162584 & 975000 & 1500000 \\
\hline 2 & Potongan & 10 & 21500 & 14347 & 0 & 50000 \\
\hline 3 & Cicilan per bulan & 10 & 115000 & 15811 & 110000 & 160000 \\
\hline 4 & Ditabung & 10 & 7200 & 2658 & 0 & 10000 \\
\hline
\end{tabular}

Tabel 5. Statistik Penerima Program Menurut Pertanyaan Evaluasi Input Program KUBE

\begin{tabular}{|c|c|c|c|c|c|c|}
\hline \multirow{2}{*}{ No. } & \multirow{2}{*}{ Jumlah uang (Rp) } & \multicolumn{5}{|c|}{ Statistik } \\
\hline & & $\mathrm{n}$ & mean & $\mathrm{sd}$ & $\min$ & $\max$ \\
\hline 1 & Bantuan yang diberikan & 10 & 650000 & 241523 & 500000 & 1000000 \\
\hline 2 & Potongan & 10 & 339400 & 384712 & 0 & 950000 \\
\hline 3 & Cicilan per bulan & 10 & 135000 & 121312 & 50000 & 440000 \\
\hline 4 & Ditabung & 10 & 5450 & 8519 & 0 & 20000 \\
\hline
\end{tabular}




\section{Proses}

Keadaan yang sama dengan PNPM, bahwa semua penerima KUBE juga tidak harus mengajukan permohonan untuk mendapatkan bantuan. Kemudahan mendapatkan bantuan dan kesesuaian jumlah bantuan yang diterima dirasakan oleh hampir semua penerima program. Berdasarkan di atas, jika dilihat dari ketepatan waktu dana diturunkan, sebagian besar $(80 \%)$ penerima menyatakan bahwa dana yang diturunkan tepat waktu. Pada program PNPM, semua penerima menyatakan adanya proses sosialisasi sedangkan pada program KUBE keberadaan kegiatan sosialisasi hanya dinyatakan oleh 60 persen penerima dan sisa tidak merasakan adanya kegiatan tersebut. Hal ini menunjukkan bahwa kegiatan sosialisasi program KUBE belum merata kesemua penerima. Hampir semua penerima (90\%) menyatakan bahwa kegiatan sosialisasi tersebut tidak melibatkan tokoh informal dan hanya setengahnya dari penerima yang sering mengikuti kegiatan sosialisasi

\section{Output}

Jika ditinjau dari segi output, maka keberhasilan PNPM lebih banyak dirasakan oleh penerima program daripada program KUBE. Hal ini dapat dilihat dari lebih banyaknya penerima program PNPM yang mengalami peningkatan penghasilan, peningkatan keterampilan usaha dan kemudahan dalam memasarkan hasil usaha. Hasil penelitian menunjukkan bahwa hanya setengah penerima program KUBE yang rata-rata penghasilannya meningkat dan 40 persen tidak merasakan adanya kemudahan memasarkan hasil usaha setelah menerima bantuan. Kondisi tersebut disebabkan karena penerima program tidak memperluas atau memperbanyak penjualannya dan masih merintis usaha baru.

Hal-hal lain yang ditemukan di lapangan adalah hampir semua (90\%) penerima program KUBE tidak merasakan adanya peningkatan keterampilan usaha. Peningkatan keterampilan dalam bentuk penambahan komoditas penjualan hanya dirasakan oleh 10 persen responden saja. Kondisi tersebut dapat saja berdampak pada kemampuan kerjasama dengan pihak lain juga menjadi rendah
P2KP

Input

Pada Tabel 6 dapat dilihat bahwa ratarata jumlah bantuan yang diberikan sebesar Rp 1203000 dan maksimum Rp 2000000 . Jika dibandingkan dengan program PNPM dan KUBE, bantuan yang diberikan oleh program P2KP lebih besar. Sebanyak 20 persen penerima program menyatakan bahwa

jumlah bantuan yang diterima dipotong ratarata Rp 307000 untuk keperluan administrasi.

Karena bantuan yang diterima bersifat pinjaman maka harus dikembalikan dengan tenggang waktu yang telah disepakati. Jika dibandingkan dengan program P2KP dan KUBE, maka waktu pengembalian pinjaman lebih bervariasi yaitu mulai 6 bulan sampai 20 bulan dengan cicilan rata-rata Rp 151 500. Hasil penelitian Evitriana (2005) di salah satu kecamatan Kota Bogor menemukan bahwa pengembalian pinjaman selama 10 bulan dengan masa tenggang dua bulan.

\section{Proses}

Berbeda dengan program PNPM dan KUBE, pada program P2KP sebagian besar $(60 \%)$ penerima harus mengajukan permohonan bantuan kepada pihak pengelola program. Meskipun demikian penerima mendapat kemudahan untuk mendapatkan bantuannya (80\%) dan merasakan bantuan yang diterima telah sesuai dengan yang diharapkan (90\%) serta dana yang diturunkan tepat waktu $(90 \%)$. Dalam hal kegiatan sosialisasi, hampir semua $(90 \%)$ penerima menyatakan adanya kegiatan sosialisasi yang melibatkan tokoh informal. Berdasarkan kajian di lapangan tidak semua penerima mengikuti kegiatan sosialisasi dan hasil analisis data menunjukkan sebanyak 30 persen penerima tidak pernah mengikuti kegiatan sosialisasi. Kondisi inilah yang perlu selalu dimotivasi pendamping program agar penerima mau mengikuti kegiatan sosialisasi dengan baik.

Kondisi yang sama dengan program KUBE bahwa sebanyak 70 persen penerima program yang mampu mengembalikan pinjaman dengan tepat waktu dan sisanya (30\%) tidak mampu melakukan hal tersebut

Tabel 6. Statistik Penerima Program Menurut Pertanyaan Evaluasi Input Program P2KP

\begin{tabular}{clccccc}
\hline \multirow{2}{*}{ No. } & \multicolumn{2}{c}{ Jumlah uang (Rp) } & \multicolumn{5}{c}{ Statistik } \\
\cline { 3 - 6 } & & $\mathrm{n}$ & mean & sd & min & $\max$ \\
\hline 1 & Bantuan yang diberikan & 10 & 1203000 & 585834 & 500000 & 2000000 \\
2 & Potongan & 10 & 307000 & 664196 & 0 & 2000000 \\
3 & Cicilan per bulan & 10 & 151500 & 164959 & 0 & 560000 \\
4 & Ditabung & 10 & 500 & 1581 & 0 & 5000 \\
\hline
\end{tabular}


meskipun sanksi tetap diberlakukan. Jenis sanksi yang diberikan kepada penerima program yang tidak tepat waktu pengembalian adalah denda. Sebanyak 90 persen penerima program juga mengakui adanya peningkatan tambahan bantuan jika dapat mengembalikan bantuan dengan tepat waktu.

\section{Output}

Hasil penelitian menunjukkan bahwa sebanyak 60 persen penerima program yang mengalami peningkatan penghasilan dan pemasaran hasil lebih mudah setelah menerima bantuan dari program P2KP. Sementara 30 persen penerima program tidak merasa pemasarannya lebih mudah karena mereka sendiri juga tidak memperluas penjualannya. Jika kondisi tersebut dibandingkan dengan keberhasilan yang dirasakan oleh penerima PNPM, maka keberhasilan P2KP lebih rendah dibandingkan keberhasilan yang dirasakan penerima PNPM.

Hal lain yang ditemukan dalam penelitian ini adalah bahwa hampir semua penerima program tidak meningkat dalam keterampilan usahanya. Sehingga kondisi tersebut menyebabkan keterampilan kerjasama juga menjadi rendah. Hal tersebut terbukti dari 80 penerima program yang menyatakan tidak ada peningkatan kerjasama dalam menjalankan usahanya.

\section{Dakabalarea}

Input

Jumlah bantuan yang diterima oleh peserta program pemberdayaan Dakabalarea paling besar dibandingkan empat program yang diamati dalam penelitian ini. Karena bantuan yang diberikan sifatnya pinjaman, maka penerima program harus mengembalikannya jangka waktu tertentu. Hasil analisis data menunjukkan bahwa penerima mampu mengembalikan bantuan tersebut antara 10 sampai 12 bulan dengan rata-rata cicilan per bulan Rp 121875 (Tabel 7).

\section{Proses}

Untuk mendapatkan bantuan dari program Dakabalarea, sebanyak 62.5 persen penerima harus mengajukan surat permohonan bantuan kepada pengelola program, sedangkan yang lainnya $(37.5 \%)$ tidak melakukan prosedur tersebut. Terdapat sekitar 25 persen penerima yang tidak mendapatkan kemudahan dalam mendapatkan bantuan. Walaupun begitu bantuan tersebut dirasakan oleh semua penerima telah sesuai dengan yang diharapkan. Jika dilihat dari waktu turunnya bantuan maka sebanyak 75 persen responden menyatakan tepat waktu. Keadaan yang sama dengan program KUBE, tidak semua penerima program Dakabalarea mengetahui adanya kegiatan sosialisasi. Hal ini ditunjukkan oleh data, dimana penerima program yang mengetahui adanya kegiatan sosialisasi hanya 37.5 persen. Dalam kegiatan sosialisasi, tokoh informal juga dilibatkan dan penerima yang mengetahui adanya kegiatan tersebut sering menghadirinya. Sebagian besar penerima $(87.5 \%)$ menyatakan tidak terdapat sanksi jika terlambat mengembalikan pinjaman. Berbeda dengan program PNPM, KUBE dan P2KP, dimana hampir semua penerima program mengakui adanya tambahan bantuan jika tepat mengembalikan pinjamannya, sedangkan pada program Dakabalarea hanya 37.5 persen yang menyatakan hal tersebut. Jadi dapat dikatakan bahwa tidak adanya sanksi dan reward yang diberikan kepada pada penerima program menyebabkan banyaknya penerima program sering telat dalam pengembalian pinjaman.

\section{Output}

Kondisi yang berbeda dengan ketiga program diatas, ternyata tidak ada penerima program Dakabalarea yang mengalami peningkatan penghasilan, bahkan terdapat 50 persen penerima program mengalami penurunan dan 37.5 persen penghasilan mereka tetap setelah menerima bantuan. Hal ini mungkin saja disebabkan karena 87.5 persen penerima program mengalami kesulitan dalam pemasaran sebagai akibat dari gagal panen. Hasil penelitian juga menunjukkan bahwa semua keterampilan usaha penerima program Dakabalarea tidak mengalami peningkatan setelah menerima bantuan. Kondisi ini juga yang mendukung terhadap ketidakmampuan penerima program dalam melakukan kerjasama dengan pihak lain. Ditinjau dari segi output maka keberhasilan program Dakabalarea lebih rendah dibandingkan dengan ketiga program yang sudah dibahas sebelumnya (PNPM, KUBE dan P2KP). Hal yang mendukung terhadap rendahnya keberhasilan program adalah rendahnya dukungan tokoh informal dan anggota keluarga, serta kurang mendukungnya potensi sumberdaya alam dan sarana transportasi.

\section{Garda Emas}

Input

Hanya sebagian kecil saja (20\%) penerima yang menyatakan bahwa uang yang diterima dipotong untuk kepentingan administrasi 
dengan rata-rata potongan Rp 3 000. Hampir semua penerima (90\%) mengembalikan pinjamannya dalam waktu 10 bulan dan yang lainnnya (10\%) dapat melunasinya dalam waktu 5 bulan. Berdasarkan Tabel 8 rata-rata cicilan yang harus dibayar adalah Rp 63600 . Oleh karena itu semua penerima program tidak pernah mendapat sanksi karena tepat waktu dalam mengembalikan pinjamannya. Meskipun 30 persen penerima program menyatakan bahwa terdapat aturan atau sanksi yang diterapkan dalam mengikuti program tersebut.

\section{Proses}

Untuk mengajukan permohonan bantuan pada program Garda Emas, maka hampir semua penerima (90\%) tidak diharuskan mengajukan surat permohonan bantuan. Meskipun dapat kemudahan dalam pengajuan tapi masih ditemukan 30 persen penerima program tidak mendapat kemudahan dalam memperoleh bantuan. Sebanyak 80 persen penerima merasa puas dengan jumlah bantuan yang diberikan dan sisanya (20\%) tidak puas karena menginginkan jumlahnya yang lebih besar lagi.

Hal ini mungkin saja terjadi karena berdasarkan pembahasan sebelumnya, bantuan dari Garda Emas paling kecil jumlahnya dibandingkan empat program pemberdayaan lain yang dikaji dalam penelitian ini. Jika ditinjau dari waktu turunnya bantuan maka 60 persen penerima menyatakan tepat waktu. Sama halnya dengan program Dakabalarea bahwa hanya sebagian penerima program Garda Emas yang mengetahui adanya sosialisasi dan sebagian besar yang mengetahui kegiatan tersebut sering mengikutinya. Menurut penerima program bahwa kegiatan sosialisasi tersebut telah melibatkan tokoh informal masyarakat setempat. Ketidaktepatan pengembalian pinjaman dialami oleh sepertiga dari penerima program. Menurut sebagian besar penerima, tidak ada sanksi yang diberikan kepada penerima program yang telat pembayaran cicilannya. Walau- pun demikian masih ada 10 persen yang pernah dikenakan sanksi berupa denda karena telat membayar.

\section{Output}

Sebanyak 70 persen penerima program Garda Emas mengalami peningkatan penghasilan setelah menerima bantuan. Namun masih ditemukan setengah dari penerima program mengalami kesulitan pemasaran hasil, yang disebabkan karena tidak memperluas penjualan dan ada juga yang masih merintis usaha baru. Hasil penelitian juga memperlihatkan bahwa 80 persen penerima program tidak mengalami peningkatan keterampilan dalam usahanya. Hampir semua penerima tidak mampu menjalin kerjasama dengan pihak lain selama mengikuti program pemberdayaan.

\section{Cost-Effectiveness Program PNPM Mandiri}

Penerima program PNPM Mandiri pada tahun 2009 di Kabupaten Bogor diperkirakan sebanyak $\mathrm{N}=11.671$ orang dengan total dana yang disalurkan sebesar D=Rp 12358430000 seperti dapat dilihat pada Tabel 9. Peluang keberhasilan program ini tergolong baik yaitu sebesar 0.80 dan lebih tinggi dibandingkan dengan program sejenis yang pernah dilakukan di Kota Bogor yaitu program Dakabalarea (0.27), program P2KP (0.36) dan program Kube $(0.72)$.

Peluang keberhasilan PNPM mandiri hanya lebih rendah dari program Garda Emas yang memiliki peluang keberhasilan sebesar 0.89. Peluang keberhasilan sebesar 0.80 memiliki pengertian bahwa jika seseorang menjalankan kegiatan usaha dan memperoleh bantuan modal dari program PNPM Mandiri maka orang tersebut akan meningkat keuntungannya dari sebelumnya dengan peluang 0.80 dan orang tersebut tidak meningkat keuntungannya atau bahkan berkurang peluangnya hanya sebesar 0.20 .

Tabel 7. Statistik Penerima Program Menurut Pertanyaan Evaluasi Input Program Dakabalarea

\begin{tabular}{|c|c|c|c|c|c|c|}
\hline \multirow{2}{*}{ No. } & \multirow{2}{*}{ Jumlah uang (Rp) } & \multicolumn{5}{|c|}{ Statistik } \\
\hline & & $\mathrm{n}$ & mean & sd & $\min$ & $\max$ \\
\hline 1 & Bantuan yang diberikan & 8 & 1437500 & 623212 & 500000 & 2000000 \\
\hline 2 & Potongan & 8 & 175000 & 341216 & 0 & 1000000 \\
\hline 3 & Cicilan per bulan & 8 & 121875 & 74639 & 0 & 200000 \\
\hline 4 & Ditabung & 8 & 0 & 0 & 0 & 0 \\
\hline
\end{tabular}

Tabel 8. Statistik Penerima Program Menurut Pertanyaan Evaluasi Input Program Garda Emas

\begin{tabular}{|c|c|c|c|c|c|c|}
\hline \multirow{2}{*}{ No. } & \multirow{2}{*}{ Jumlah uang (Rp) } & \multicolumn{5}{|c|}{ Statistik } \\
\hline & & $\mathrm{n}$ & mean & sd & $\min$ & $\max$ \\
\hline 1 & Bantuan yang diberikan & 10 & 525000 & 184466 & 250000 & 1000000 \\
\hline 2 & Potongan & 10 & 3000 & 6749 & 0 & 20000 \\
\hline 3 & Cicilan per bulan & 10 & 63600 & 36148 & 0 & 122000 \\
\hline 4 & Ditabung & 10 & 2300 & 4111 & 0 & 10000 \\
\hline
\end{tabular}


Program PNPM Mandiri mampu memberikan rataan tambahan pendapatan sebesar $\mathrm{Rp}$ $341000 /$ bulan. Tambahan keuntungan ini sudah tergolong baik karena modal yang dipinjamkan umumnya hanya berkisar antara Rp 500000 sampai Rp 2000000 per penerima. Bagi pemula program PNPM meminjamkan pinjaman modal sebesar Rp 500000 per penerima dan pada pengajuan berikutnya pinjamannya dapat meningkat secara bertahap sampai Rp 2000000.

Dalam kurun waktu 25 tahun ke depan dari total dana yang disalurkan sebesar 12 milyar rupiah lebih, nilai PDB yang dapat diselamatkan atau dihasilkan diperkirakan sebesar Rp 496972178965 . Jika dihitung per tahun maka PDB yang dapat diselamatkan rata-rata sekitar Rp 20 milyar. Hal ini menunjukkan bahwa nilai PDB per tahun yang dihasilkan sebesar 1.8 kali dari modal yang disalurkan kepada para penerima.

Rataan usia penerima program PNPM mandiri adalah sekitar 40 tahun. Jika batas usia produktif 65 tahun maka rataan jangka waktu menjalankan usaha penerima bantuan modal dari program ini selama 25 tahun. Rataan rentang waktu program ini lebih lama dibandingkan penerima program sebelumnya di Kota Bogor yaitu Dakabalarea (16 tahun), Garda Emas (22 tahun), P2KP (21 tahun) dan Kube (17 tahun). Rentang waktu menjalankan usahanya lebih lama karena rataan umur penerima program PNPM Mandiri lebih muda.

Program PNPM mandiri adalah program pemberdayaan yang efektif karena memiliki $1 / C E=40.21>0$. Nilai ini memiliki pengertian bahwa setiap nilai satu rupiah yang disalurkan lewat program PNPM mandiri dalam jangkan waktu 25 tahun kedepan dapat menghasilkan PDB sebesar Rp 40.21 atau sebesar Rp 1.58 per tahun. Jika nilai $1 /$ CE per tahun dibandingkan dengan program yang pernah dilakukan di Kota Bogor, nilai $1 /$ CE per tahun ini hanya lebih tinggi daripada nilai $1 /$ CE program Dakabalarea ( $R p$ 0.91), namun lebih rendah dari nilai 1/CE program Garda Emas (Rp 2.81), P2KP (Rp 3.72) dan Kube (Rp 14.89).

Tabel 9. Evaluasi cost-effectiveness Program PNPM Mandiri

\begin{tabular}{lcc}
\hline \multicolumn{1}{c}{ Peubah } & Kode & Besaran \\
\hline Rataan Tambahan Pendapatan Rp/bulan akibat menerima program & $\mathrm{K}$ & 341000.00 \\
Ukuran sampel & $\mathrm{n}$ & 10.00 \\
Sampel yang usahanya memberikan tambahan positif keuntungan & $\mathrm{m}$ & 8.00 \\
Peluang berhasil & $\mathrm{P}$ & 0.80 \\
Rataan umur saat menerima program (tahun) & & 39.63 \\
Rataan umur saat menerima program (bulan) & & 475.50 \\
Usia tidak produktif (thn) & & 65.00 \\
Usia tidak produktif (bln) & $\mathrm{b}$ & 780.00 \\
Rataan lama usaha sampai pensiun & $\mathrm{r}$ & 304.50 \\
Bunga bank per bulan & $\mathrm{D}$ & 0.01 \\
Total penggunaan Dana (Rp) & $\mathrm{N}$ & 12358430000.00 \\
Perkiraan Banyaknya penerima program & $\mathrm{PDB}$ & 4969721.00 \\
Produk Domestik Bruto yang dapat diselamatkan (PDB) Rp & $\mathrm{CE}$ & 0.02 \\
Cost Effectiveness Program & $1 / \mathrm{CE}$ & 40.21 \\
Nilai PDB (Rp) yang dapat diselamatkan oleh Rp 1 program & & 25.38 \\
Rataan Rentang waktu (tahun) yang dijalankan penerima & & 1.58 \\
Nilai PDB (Rp) yang dapat diselamatkan oleh Rp 1 program per tahun & &
\end{tabular}




\section{KESIMPULAN}

Ditinjau dari segi input, proses dan ouput, program PNPM Mandiri relatif lebih baik dibandingkan dengan empat program lainnya (KUBE, P2KP, Dakabalarea dan Garda Emas). Sedangkan program pemberdayaan yang kualitas outputnya masih rendah adalah Dakabalarea.

Program PNPM mandiri adalah program pemberdayaan yang efektif karena memiliki $1 / C E=40.21>0$. Nilai ini memiliki pengertian bahwa setiap nilai satu rupiah yang disalurkan lewat program PNPM mandiri dalam jangka waktu 25 tahun kedepan dapat menghasilkan PDB sebesar Rp 40.21 atau sebesar Rp 1.58 per tahun. Program PNPM Mandiri ini lebih efektif daripada program Dakabalarea, namun efektivitasnya lebih rendah daripada program Garda Emas, P2KP, dan KUBE.

Peluang keberhasilan program ini tergolong baik yaitu sebesar 0.80 dan lebih tinggi dibandingkan dengan program sejenis yang pernah dilakukan di Kota Bogor yaitu program Dakabalarea (0.27), program P2KP (0.36) dan program Kube (0.72). Peluang keberhasilan PNPM mandiri hanya lebih rendah dari program Garda Emas yag memiliki peluang keberhasilan sebesar 0.89 .

\section{DAFTAR PUSTAKA}

Khomsan A. 2007. Kemiskinan, Kesejahteraan, dan Kebahagiaan. Kompas, 16 Juni.

Engel JF, RD Blackwell, PW Miniard. 1992. Perilaku Konsumen Jilid I. Binarupa Aksara, Jakarta.

Amrullah A. 2000. Studi Evaluasi Tabungan Keluarga Sejahtera dan Kredit Usaha Keluarga Sejahtera di Kabupaten Soppeng. Tesis Sarjana Gizi Masyarakat dan Sumberdaya Keluarga. Program Pasca Sarjana, Institut Pertanian Bogor, Bogor.

LD UI. 1981. Dasar-Dasar Demografi. Penerbit FE, UI, Jakarta.

Tjahjana T. 2004. Analisis Perubahan Sosial Ekonomi Petani Padi Sawah Pinggiran Kota. Universitas Padjadjaran, Bandung. 